\title{
Reserve labor, unreserved politics: dignified encroachments under India's national rural employment guarantee act
}

Indrajit Roy

\begin{abstract}
The rural proletariat constitute a substantial proportion of the global poor. Leading better lives is central to their political practices. In this paper, I aim to elaborate the political practices that attend to these aspirations, interrogations and contests. I examine existing approaches to studying political practices of the rural proletariat. I do this with a focus on India, where the National Rural Employment Guarantee Act (NREGA) is in force since 2005. I locate the program against the backdrop of neoliberal transformations in India. I then examine the ways in which the rural proletariat engage with the program, even when other opportunities in the agricultural sector are available. Based on these examinations, I argue that the practices spawned by the program are to be understood as 'encroachments' into the extant social customs, norms and habits of rural India. This perspective, I contend, is more fruitful than locating the rural proletariat's engagement with the NREGA as a coping strategy or a tactic of resistance against rural elites. The data which this paper draws on include official sources, in-depth interviews with workers in rural Bihar and West Bengal and ethnographic observations.
\end{abstract}

Keywords: rural proletariat; work; encroachments

\section{Introduction: agrarian crisis and rural employment}

An important 'problematic' of the contemporary world has been the refusal of the 'peasant' to fade away, as scholars of the Left and the Right of the political spectrum had thought long overdue. Henry Bernstein notes that 'peasants' today are not exclusively engaged in farming but 'combine agricultural petty production (including subsistence ...) with a range of other economic activities' (Bernstein 2001, 31). A crucial constituent of the peasantry is the rural proletariat (Mintz 1974, Breman 1996), those alienated from the means of production. They are compelled to hire out their manual labor in exchange for wages that barely sustain them. Where such alienation is sustained by institutionalized social discrimination, the inequalities they produce are durable indeed (Tilly 1999). Transformations in contemporary globalism have had ambivalent outcomes for these inequalities: at best they have bypassed them, while at worst the chronic forms of poverty and exploitation they have produced have exacerbated these inequalities (Bird et al. 2002, Akram-Lodhi

I would like to thank Barbara Harriss-White, David Gellner and James Holston, as well as participants in workshops at Berkeley and Oxford. As ever, I remain grateful to my hosts and interlocutors in Araria and Maldah districts in eastern India for invaluable insights. The usual disclaimers apply. 
and Kay 2009, Borras 2009). Leading better lives in the face of these inequalities is central to the politics of the rural proletariat.

In this paper, I aim to elaborate the political practices that attend to these aspirations. I do this with a focus on India, where the USD ${ }^{1} 8$ billion National Rural Employment Guarantee Program is being implemented, beginning in 2005, under the aegis of the National Rural Employment Guarantee Act (NREGA). In this paper, I use the legislation and the program interchangeably. I locate the program against the backdrop of agrarian distress in India. I then examine the ways in which the rural proletariat engages with the program, even when other opportunities in the agricultural sector are available. Based on these examinations, I argue that the practices spawned by the program are to be understood as 'encroachments' into the extant social customs, norms and habits of rural India. This perspective, I contend, is more fruitful than locating the rural proletariat's engagement with the NREGA as a coping strategy or a tactic of resistance against rural elites. An important, although underutilized, contribution to this field has been made by Asef Bayat (2000, 2010), and I will build on, as well as amend, his formulation.

A glance at the changes in the profile of India's agricultural spaces and workforce points to the agrarian distress that characterizes its countrysid ndlessness among rural households is increasing (Government of India 2006). Side by , the ranks of 'marginal' 2 landholdings have swelled in recent years, indicating a simultaneous fragmentation of the rural landscape and convergence in the type of landholdings (Government of India 2011). In general, the profile of work in India has tended towards reduction in the number of cultivators, ${ }^{3}$ increase in agricultural laborers ${ }^{4}$ and growth in the number of 'marginal workers' (Government of India 2011) and casualization (Government of India 2008). It is clear that what India is experiencing is rural proletarianisation. ${ }^{6}$

\subsection{NREGA: at the intersection of official, advocacy and everyday politics}

Under these circumstances, the passage in 2005 by the Indian Government of the National Rural Employment Guarantee Act was welcomed by many. The Act guaranteed work for 100 days to members of any rural household that demanded it, indexing the wage to the level of agricultural minimum wage. ${ }^{7}$ Supporters and sympathizers praised the passage of the act as 'a victory of sorts for Indian democracy' (Drèze 2011, 5). More circumspect observers have asked whether the program acts as a palliative for the rural proletariat who bear the brunt of the accumulation attempts by the Indian state (Vasavi 2012). However, few authors have examined the sociology of the program and the ways in which workers actually engage with it (for a significant exception, see Khera and Nayak 2011). What meanings do they attribute to it, and how do they seek to utilize it in their repertoires for

\footnotetext{
${ }^{1} 1 \mathrm{USD}={ }^{\prime} 18$ in terms of purchasing power parity.

${ }^{2}$ A household is classified as 'marginal' if it owns less than one hectare of land: marginal farmers are extremely livelihood-insecure, often hiring out their labor to other, wealthier farmers.

${ }^{3}$ 'Cultivators' refers to those who cultivate land that is owned or held by them.

4'Agricultural laborers' are those who work on lands held or owned by others in exchange for wages in cash, kind or a combination of both.

${ }^{5}$ 'Marginal workers' are workers who find employment for up to six months in a year. By contrast, 'main workers' are workers who find employment for more than six months in a year.

${ }^{6}$ Further evidence is provided in Sainath (2011a and 2011b).

${ }^{7}$ Outside Parliament, the virulent opposition to the program by fiscal conservatives constrained the terms of the debate as to whether it was fiscally sustainable or not, and whether it was the best means of addressing rural poverty. These debates have been aptly summarized in Drèze (2011).
} 
achieving security and dignity? What identities are affirmed through their association with the program? How does their engagement with this program intersect with the ongoing political practices?

These questions about the implementation of the NREGA and its relationship with the identities, relationships and practices of the workers engaged with it compel us to consider different analytical approaches to rural politics, categorized by Ben Kerkvliet (2009) as official politics, advocacy politics and everyday politics. The NREGA itself is an example of 'official politics', originating as it does from official legislation and supplementary ordinances. Actions and decisions of bureaucrats and politicians influence the implementation of the program. They are often confronted, by local activists, cadres of radical political parties and those employed with the program, with different kinds of demands relating to the implementation of the program. These represent strands of 'advocacy politics'. Both official and advocacy politics are intertwined with quotidian negotiations of the workers in their bid to affirm their association with the program and use it to their own interests. Rural workers utilize the program to 'encroach' into public spaces from which they were previously excluded. This paper is an attempt to examine these encroachments.

\subsection{Research methods}

The arguments I make here are based on a combination of secondary data analysis, especially official data on patterns of employment generated during the agricultural seasons; in-depth interviews with workers on NREGA projects; and field notes from observer-participation and ethnographic 'hanging out'. The paper draws on data from two States in eastern India, namely Bihar and West Bengal. Official data is presented for the States as well as for one Panchayat, the most basic unit of governance in rural areas. Ethnographic data pertains to a select ward within the Panchayats.

Official data on the seasonal patterns of NREGA work has been analyzed for three years, from 2009-10 to 2011-12. The number of persondays was aggregated over the year and then the monthly proportion of persondays was calculated. The years are organized along the April-March cycle to reflect the local cropping cycle. The data is then analyzed in relation to the different seasons.

While drawing on official data, I take seriously Shahid Amin's (1995) warning about the juridical archive being the 'state's emissary'. I am therefore insistent on juxtaposing the official data with perspectives gleaned from ethnographic hanging out with as well as focused conversations with workers, agriculturalists and other inhabitants of the study localities.

The purpose of this paper is thus three-fold. The first is to propose that the NREGA be located against the backdrop of the agrarian crisis that plagued the country through much of the previous decade. The second is to provide data on seasonal employment patterns from select parts of India, and to examine what that might reveal about the transforming socioeconomic relationships and political practices in rural India. The third is to stimulate reflections about the quotidian political world of the rural proletariat in terms that foreground their narratives.

A note clarifying the meanings of the terms used in this paper is in order. By 'rural proletariat', I refer to agricultural labor households, especially those who are landless. Many landless families lease land from agriculturalists, but do not actually own the land. I also include within this category the holders of marginal-sized land plots, as they face precarious livelihoods and often hire out their labor. By 'agricultural labourer', I follow the Indian government's definition and refer to those who hire out their labor to work on the fields 
of agriculturalists: agricultural laborers are a subset of the rural proletariat. By agriculturalists, I refer to households that cultivate land which they own or lease. This is synonymous with the term 'cultivator' used by the Indian government. Some agriculturalists may hire out their labor and hence be considered rural proletariat. By 'rural worker', I refer to workers who actually work on NREGA projects: these are almost always likely to be members of the rural proletariat. However, I refer to them as 'workers' to emphasize their relation with their employment in the program.

\subsection{The NREGA and Indian agriculture}

The program's guidelines oblige the state to respond to an application for work by providing it within 15 days. A failure to meet this obligation makes claimants eligible to receive unemployment allowance (berozgaari bhatta). The employment provided must be for a minimum of 14 consecutive days. The government is required to provide employment within a radius of five kilometers, irrespective of the number of applicants. Wage payments are to be made within seven days of the execution of the work. ${ }^{8}$

Important though the introduction of the NREGA is, it is crucial that the agrarian crisis that forms the backdrop to its introduction not be obscured (Reddy and Misra 2009, 28). Vasavi (2012) has applied the notion of 'agrarian involution' to describe the agrarian crisis that has enveloped India during the last two decades. She refers to the integration of new forms and practices in agriculture while maintaining established social structures and deploying them for the purpose of strengthening the new forms and practices. Thus, the use of new techniques and institutional arrangements for cropping coexist with the retention of caste as the social basis of agriculture. The logics of profit-making and reduction of unproductive investments are central to institutional improvements in agriculture. The downside for agricultural laborers is that their exploitation for agricultural production continues, and is socially sanctioned by structures of caste exploitation (Bayly 1999). Moreover, the few safety nets upheld by feudal customs have been eliminated in order to free resources for more 'productive' use. Considering that the overwhelming majority of agricultural laborers are drawn from communities stigmatized as 'untouchable', they face the twin burden of economic exploitation and social oppression. That these communities bear the brunt of the inequitable agrarian-structure is not in doubt. While they comprise 16 percent of the total population of the country, they make up 32 percent of the population of agricultural laborers (Government of India 2008, 117). While 36 percent of the total population of agriculturalists owned 'sub-marginal' farm plots (less than 0.04 hectares), nearly 57 percent of the agriculturalists from these communities did so (Government of India 2008, 118). Thus, it would not be incorrect to say that they have been the primary victims of the agricultural involution to which Vasavi draws our attention.

The inexorable fragmentation of landholdings and the squeeze in farm profits have made it increasingly unviable for agriculturalists to maintain traditional means of sustaining agricultural laborers during the lean season. This situation is exacerbated by increased labor shortages. Political mobilizations among the rural proletariat along class and caste lines

\footnotetext{
${ }^{8}$ In a politically astute move, the wage component of the program is met by the Central Government's funds, but the unemployment allowance component needs to be borne by the State Government. This was expected to incentivize the State Government to ensure that job applications are fulfilled within the prescribed time limit.
} 
have increased their assertiveness vis-à-vis local elites (Hauser 1993, Kunnath 2012). Moreover, agricultural laborers are increasingly cognizant of alternative employment opportunities in towns and other States. Here, social discrimination is less acute and wages are higher. Convenient railway connections and contacts with potential employers facilitate the movement of laborers to and from their villages of origin.

Now, farmers who have 'improved' their agricultural techniques find that the timing of labor availability is more crucial than ever before. After all, 'labor is worth its hire only at certain times, but is critical at those times ...' (Herring and Edwards 1983, 586). But such farmers do not need laborers during the slack seasons, and are unable and unwilling to sustain them during these periods. Public work programs designed to provide employment for the rural poor over a fixed number of days through the year are often seen as a means of sustaining a 'reserve army of labor'. These programs provide work to the agricultural laborers during the lean season, inducing them to stay on in the village. They can then be deployed on the fields during the peak season. Theoretically at least, such an arrangement results in a win-win situation: for rural laborers who need employment, for agriculturalists who do not have to make 'unproductive' investments in sustaining labor but can still call on labor when required, and for the state which does not have to deal with restive populations.

However, in a remarkable break from all previous public work programs, the NREGA guidelines do not impose any seasonal restrictions on the execution of projects. By allowing projects during the cropping season, they do not prevent claimants from working on them during agricultural seasons. Payments to workers are higher than the wage paid in the local labor market, thereby offering workers the opportunity to obtain better-paying employment than what local agriculturalists pay. Where backed by effective protections for workers who opt to work for the NREGA rather than for local agriculturalists, the program does seem to offer a genuine set of alternatives to workers. This aspect of the official politics of the NREGA has profound implications for the reconfiguration of social relations in the countryside.

However, it is not clear whether or how it can reverse the crisis in agriculture. The allocations to the program have attracted much attention from both sympathetic liberals and fiscal conservatives. Nonetheless, some perspective is important here. The expenditure on the NREGA, impressive though it was at nearly ₹30,000 crores $^{9}$ (approximately USD 7 billion), in 2012-13 represented 0.05 percent of the annual budget expenditure (Government of India 2013, 8, 273). This proportion has not been substantially higher in the previous years, when expenditure on the program was at its peak. ${ }^{10}$ On the other hand, the expenditure on agriculture and allied services (including irrigation) during the same year was less than ₹ 18,000 crores, or slightly over half the total expenditure on the NREGA. This expenditure differential represents a continuity (demonstrated in Table 1) rather than a reversal of the trend since the mid-1990s.

\section{The seasonality of work}

The rural proletariat appears to have embraced the opportunities available under the NREGA. Between 2009-10 and 2011-12, approximately 75 million to 85 million persons (representing about 10 percent of the country's rural population) worked on the

\footnotetext{
${ }^{9} 1$ crore $=10$ million.

${ }^{10}$ India's National Budget Expenditure in 2012-2013 was calculated at ' $\mathbf{1 4 3 0 8 2 5}$ crores.
} 
Table 1. Percent allocations for the agriculture and rural development sectors to total budget expenditure.

\begin{tabular}{lccc}
\hline Sector & $1995 / 6$ & $2002 / 3$ & $2010 / 11$ \\
\hline Agriculture and allied services (including irrigation) & 1.57 & 0.34 & 1.33 \\
Rural development (including rural employment) & 3.54 & 1.94 & 3.62 \\
\hline
\end{tabular}

Source: Budget documents, various years.

program each year. Indeed, the numbers of people demanding and obtaining work under the program in the States has been staggering, especially given the program's manifold imperfections (Khera 2011). ${ }^{11}$

However, it is important to note that NREGA projects are often announced by bureaucrats during cropping cycles. These are rarely in response to 'demands' by the workers, as the guidelines envisage. As a result, workers are actually compelled to choose between employment on NREGA work and employment in agriculture. An analysis of the timing of NREGA work, as shown in Figure 1 for West Bengal and Figure 2 for Bihar, testifies to this. For the purpose of my analysis here, the choices workers make reveal a fascinating shift in the ways in which they relate to their socio-political environment, and a transformation in their engagement with the public space in their villages.

\subsection{NREGA employment patterns in West Bengal...}

The implications of the NREGA program for agricultural laborers employed as farm hands are borne out by examining the employment trends during West Bengal's major cropping seasons. As of 2008-2009, over two-thirds of the State's gross cropped area was under paddy cultivation (Government of India, n.d., Table III). The agricultural seasons are structured by the aus, aman and boro paddy seasons. Details for these crops are presented in Table 2. It is clear from the table that the more widespread aman crop is cheaper to produce and is more popular among holders of marginal size-class plots. It is typically sown during the summer months (May/June). Transplantation, a highly labor-intensive activity, takes place within four to six weeks (July/August), and the crop is harvested in the winter (December/January).

Figure 1 presents data on the monthly availability of NREGA employment through the years 2009-10 to 2011-12. It maps this data against the four major cropping seasons in the State: three rice crop seasons and one wheat crop. The broad activities under the cropping seasons - viz. sowing and harvesting - are indicated against the months in which these activities are undertaken. The data is presented for West Bengal as well as Majhipur Gram Panchayat, from where ethnographic data was gathered.

In general, it is clear that employment on the NREGA disregards the local cropping cycle. An important exception is the drastic reduction in the supply of work during the months of July and August, the Monsoon season.

However, what is really intriguing is the pattern of employment during the boro cropping season, which is associated with better-off agriculturalists, as can be observed from

\footnotetext{
${ }^{11}$ While these figures are impressive, it is also important to bear in mind that, throughout India, members of as few as 2 million households were able to secure the full 100 days of employment with the program during each of the years.
} 


\begin{tabular}{|c|c|c|c|c|c|c|c|c|c|c|c|c|}
\hline & Apr & May & Jun & Jul & Aug & Sep & Oct & Nov & Dec & Jan & Feb & Mar \\
\hline \multicolumn{13}{|c|}{ WEST BENGAL } \\
\hline Paddy (Aus) & & & & 1 & & & & & & & & S \\
\hline Paddy (Aman) & \multirow{2}{*}{\multicolumn{2}{|c|}{$\mathrm{H}$}} & & \multicolumn{2}{|c|}{$\mathrm{T}$} & & & & \multirow{2}{*}{\multicolumn{2}{|c|}{$\mathrm{H}$}} & \multirow{3}{*}{$\mathrm{T}$} & \\
\hline Paddy (Boro) & & & & & & & & S & & & & \\
\hline Wheat & $\mathrm{H}$ & & & & & & & \multicolumn{2}{|r|}{ S } & & & $\mathrm{H}$ \\
\hline 2009-2010 & 11.04 & 6.13 & 9.79 & 7.49 & 3.96 & 4.80 & 5.60 & 5.80 & 6.42 & 11.81 & 13.31 & 13.86 \\
\hline 2010-2011 & 17.01 & 16.26 & 14.59 & 7.41 & 4.06 & 3.97 & 3.18 & 2.88 & 4.87 & 8.35 & 9.93 & 7.49 \\
\hline 2011-2012 & 5.95 & 3.27 & 4.84 & 3.04 & 2.36 & 3.13 & 2.67 & 4.11 & 9.57 & 15.41 & 23.94 & 21.71 \\
\hline \multicolumn{13}{|c|}{ MAJHIPUR GRAM PANCHAYAT } \\
\hline 2009-2010 & 11.66 & 0.00 & 35.34 & 30.65 & 11.30 & 0.00 & 0.00 & 0.00 & 0.00 & 0.00 & 0.00 & 11.06 \\
\hline 2010-2011 & 9.52 & 3.87 & 19.02 & 7.08 & 20.73 & 4.87 & 7.48 & 0.00 & 0.00 & 0.52 & 8.39 & 18.52 \\
\hline 2011-2012 & 6.38 & 3.04 & 16.24 & 13.08 & 3.78 & 8.77 & 3.70 & 6.26 & 11.48 & 8.19 & 8.95 & 10.11 \\
\hline
\end{tabular}

Figure 1. Cropping seasons and employment provisioning in West Bengal and select panchayats (percent of annual workdays distributed through the months). $\mathrm{S}=$ Sowing, $\mathrm{T}=$ Transplanting, $\mathrm{H}$ - Harvesting.

Source: Authors' own calculations from NREGA website, Government of India (n.d. e.).

\begin{tabular}{|c|c|c|c|c|c|c|c|c|c|c|c|c|}
\hline & Apr & May & Jun & Jul & Aug & Sep & Oct & Nov & Dec & Jan & Feb & Mar \\
\hline \multicolumn{13}{|c|}{ BIHAR } \\
\hline Wheat & $\mathrm{H}$ & & & & & & & & & & & \\
\hline Paddy(Kharif) & & & S & & $T$ & & & $\mathrm{H}$ & & & & \\
\hline Maize & & & & & & & & S & & & \multicolumn{2}{|c|}{$\mathrm{H}$} \\
\hline Jute & s & & & & & $\mathrm{H}$ & & & & \multicolumn{2}{|r|}{$\mathrm{H}$} \\
\hline $2009-2010$ & 8.20 & 14.38 & 17.19 & 3.11 & 4.19 & 2.94 & 4.10 & 6.09 & 8.29 & 9.42 & 10.36 & 11.72 \\
\hline $2010-2011$ & 11.04 & 13.53 & 11.33 & 6.16 & 5.58 & 6.77 & 5.41 & 5.73 & 8.91 & 9.60 & 9.43 & 6.53 \\
\hline $2011-2012$ & 16.18 & 11.66 & 6.73 & 5.16 & 5.28 & 4.97 & 6.76 & 8.79 & 8.65 & 4.95 & 11.69 & 9.19 \\
\hline \multicolumn{13}{|c|}{ SARGANA GRAM PANCHAYAT } \\
\hline $2009-2010$ & 0 & 0 & 10.91 & 0 & 0 & 0 & 0 & 16.95 & 0.00 & 41.28 & 0.00 & 30.87 \\
\hline $2010-2011$ & 0 & 0 & 0 & 0 & 5.06 & 10.70 & 14.61 & 24.46 & 8.79 & 0.05 & 28.88 & 7.45 \\
\hline 2011-2012 & 15.57 & 23.62 & 0.00 & 11.18 & 8.06 & 10.94 & 3.18 & 0.66 & 17.06 & 1.02 & 7.87 & 0.83 \\
\hline
\end{tabular}

Figure 2. Cropping seasons and employment provisioning in Bihar and select panchayats (percent of annual workdays distributed through the months). $\mathrm{S}=$ Sowing, $\mathrm{T}=$ Transplanting, H- Harvesting. Source: Authors' own calculations from NREGA website, Government of India (n.d. e.).

Table 2. In 2009-10, employment on NREGA work was the second highest for that agricultural year during February, the boro transplanting season. In 2011-12, employment actually peaked during this month. During other times of the boro cropping cycle too, employment continued to be high, as, for instance, during the two harvesting months of April and May during 2010-11: nearly one-third of all NREGA work for that year was made during those two months. Thus, the disregard of the NREGA workers for the agrarian economy and society becomes even more pronounced during the boro transplanting and harvesting season.

From the way the NREGA is implemented in Majhipur, it is clear that bureaucrats pay scant attention to the cropping cycles while implementing the NREGA. The livelihood 
Table 2. Cropping patterns in West Bengal for two principal crops, 2008-9.

\begin{tabular}{|c|c|c|c|}
\hline Attribute & Aman & Boro & Source \\
\hline$\%$ of Gross Cropped Area & 43 & 16 & $\begin{array}{l}\text { Government of India (n.d. a) } \\
\text { Parts } 1 \text { and 3: Area under } \\
\text { crops in West Bengal during } \\
2008-9\end{array}$ \\
\hline Per quintal production cost () & 475 & 602 & Adhikari et al (n.d., 54) \\
\hline $\begin{array}{l}\text { Cost of irrigation as \% of } \\
\text { production cost }\end{array}$ & 1 & 15 & - do- \\
\hline Operational seasons & Kharif & Rabi & \\
\hline Sowing & May/June & November/ & Field notes and observations \\
\hline Transplantation & July/ August & December & \\
\hline \multirow[t]{2}{*}{ Harvest } & December/ & February & \\
\hline & January & April/ May & \\
\hline
\end{tabular}

options before agricultural laborers in the two Gram Panchayats appear constricted due to the officials offering employment on NREGA programs during agricultural seasons. Nonetheless, faced with a choice, rural workers engage with the NREGA ${ }^{12}$ rather than with agricultural work.

Although the official wage rate during the field work was a day (through 2009), workers reported receiving between an $\left(D\right.$ per day. ${ }^{13}$ Whil pryments were scheduled to be made within one week of comprenng the assigned work, they were frequently delayed. Agricultural laborers were employed mostly by agriculturalists owning small- and mediumsized plots of arable land. My discussions with agricultural laborers indicated that they obtained work on agriculturalists' fields for between 50 and 60 days in a year. Their availability and willingness to work was crucial for the production of the paddy crop.

This was especially so during the time-sensitive period of transplantation. Transplantation involved the puddling and leveling of the land for transplanting, making bundles of the paddy saplings for transplantation, and the actual act of transplantation. The labor intensiveness of transplantation cannot be overstressed. Transplanting 100 saplings over a plot of two bighas ${ }^{14}$ typically takes 12 women about four hours to complete. Each of the activities related to transplantation were remunerated a per day, with an additional meal provided after the actual transplantation. Labor was arod needed for the removal of weeds, and eventually for the harvesting of the crop. The harvesting of the crop was also a time-sensitive and labor-consuming activity. Labor employed during the harvest was remunerated in a combination of cash and kind, along with daily provision of meals during their employment. These permutations varied in and around the area. Sometimes payments were made entirely in kind with a seventh of the harvest share being assigned to the entire group of laborers to divide up among themselves; no meals were provided. At other times, a ninth of the harvest was assigned along with some cash (it was not

\footnotetext{
${ }^{12}$ Interestingly enough, very little employment was forthcoming during the period from September to November when few agricultural operations were implemented. This phenomenon remains to be studied.

${ }^{13}$ The rest was pocketed by the ensemble of actors that included the Post Master, Rozgar Sevak, and the elected representative who claimed to expedite the payment of the wages in the first place.

${ }^{14} 7.5$ bighas $=1$ hectare in Bengal regions ( 3 bighas $=1$ acre $=0.4$ hectare). Note that there are enormous variations throughout South Asia.
} 
Table 3. Wage rates in West Bengal. NREGA and agricultural wages compared.

\begin{tabular}{lcllc}
\hline Month (1) & $\begin{array}{c}\text { Official NREGA } \\
\text { wage }\end{array}$ & Actual payment & State-level prevailing & Locality-specific \\
January 2009 & 75 & $60-70$ & $78 / 71$ (Aman Harvest) & 60 \\
February 2009 & 75 & $60-70$ & $81 / 72$ (Boro transplant) & 45 \\
April 2009 & 75 & $60-70$ & $80 / 71$ (Boro Harvest) & 70 \\
July 2009 & 75 & $60-70$ & $\begin{array}{l}\text { 85/76 (Aman } \\
\text { transplant) }\end{array}$ \\
January 2010 & 100 & $70-80$ & 85/70 (Aman Harvest) & 70 \\
February 2010 & 100 & $70-80$ & $87 / 71$ (Boro transplant) & 50 \\
April 2010 & 100 & $70-80$ & $91 / 74$ (Boro Harvest) & 70 \\
\hline
\end{tabular}

Sources: Column 2: Government of India (n.d. f.).

Column 4: For January/February/April 2009: Government of India (2010, Tables 9a, 10a \& 12a); For July 2009: Government of India (2011c, Table 3a); For January/February/April 2010: Government of India (2012b, Table 9a, 10a and 12a). Column 4 shows wages of men and women respectively.

Columns 3 and 5: Field notes and observations.

clear to me exactly how much) or daily meals while the laborer was engaged in the harvest process. I attempt to provide a comparison in cash through Table 3.

The presence of in-kind payments to agricultural laborers makes it difficult to compare the wages under the NREGA with the agricultural wages. The NREGA wage was only sometimes slightly higher than what was paid to agricultural laborers. Moreover, the 'in-kind' component of the agricultural wages met crucial, and immediate, household requirements even as it protected laborers from inflationary pressures.

Another major difference between the two kinds of payments was the time lag between the activities performed and the actual payment. Payments under the NREGA were frequently delayed. This meant that workers did not have ready cash to purchase daily supplies, and remained dependent on credit lines from local moneylenders and retailers for most payments. On the other hand, agriculturalists were usually prompt in making their payments, whether in cash or kind. Where payments were made on a daily basis (for example, during transplanting), delays in payments by agriculturalists threatened the supply of labor as workers would cease to engage with the activity if they were not paid at the end of the day; this could be fatal to the crop. Moreover, delays in payments by agriculturalists hurt their reputation as employers, and would potentially keep away laborers in the future.

Despite the obvious advantages of working on agricultural operations, laborers took up employment under the NREGA whenever there was a choice. They did so even when payments were delayed, and when a portion thereof was used to line the pockets of the bureaucrats and politicians associated with its implementation. Admittedly, we are talking about only 15-20 days of the entire year for which work on the NREGA is actually offered. But the goings-on in those 20 days - when laborers choose to engage with the NREGA rather than the agriculturalists' farms - provide us with invaluable insights into the fundamental transformations characterizing rural society today.

\section{2. ... and in Bihar}

Table 4 provides data on cropping activities in Bihar. The first agricultural activity is marked by the sowing of the kharif paddy in May through June. The crop is transplanted in July and August, and harvested in November. The second major crop in the State is 
Table 4. Cropping patterns in Bihar for two principal crops, 2008-9.

\begin{tabular}{|c|c|c|c|}
\hline & Paddy & Wheat & Source \\
\hline$\%$ of Gross Cropped Area & 34 & 29 & $\begin{array}{l}\text { Government of India (n.d. b) } \\
\text { Parts } 1 \text { and 3: Area under crops } \\
\text { in Bihar during 2008-9 }\end{array}$ \\
\hline$\%$ of crop on irrigated land & 40 & 89 & $-\mathrm{do}-$ \\
\hline $\begin{array}{l}\text { Minimum Support Price ('per } \\
\text { quintal) }\end{array}$ & 950 & 1100 & Government of India (n.d. c) \\
\hline $\begin{array}{l}\% \text { crop cultivators who operate } \\
\text { marginal landholdings }\end{array}$ & 75 & 67 & $\begin{array}{l}\text { Government of India (n.d. d) } \\
\text { Table 6B: Estimated irrigated } \\
\text { and unirrigated area by size } \\
\text { classes under crop }\end{array}$ \\
\hline $\begin{array}{l}\text { \% crop cultivators who operate } \\
\text { small landholdings }\end{array}$ & 12 & 16 & - do- \\
\hline $\begin{array}{l}\text { \% crop cultivators who operate } \\
\text { semi-medium, medium \& large } \\
\text { landholdings }\end{array}$ & 13 & 16 & $-\mathrm{do}-$ \\
\hline Operational seasons & Kharif & Rabi & \\
\hline$\overline{\text { Broadcasting/ Sowing }}$ & May/ June & November/ & field notes and observations \\
\hline Transplantation & July/ & December & \\
\hline \multirow[t]{2}{*}{ Harvest } & August & & \\
\hline & November & March/ April & \\
\hline
\end{tabular}

wheat. The principal rabi crop, it is sowed at the onset of winter (November-December), to be harvested at the end of spring (March-April). From the table, wheat cultivators appear to be wealthier than their rice-growing counterparts. Maize, the State's second most popular rabi crop, is sown in autumn, and harvested at the end of winter (February). In the Araria district, where the Bihar study localities are located, jute is an important kharif crop (crop acreage: 1.5 percent of the State but 12 percent in Araria, the district where my ethnographic fieldwork is located). The crop is sown in April and harvested in September.

As we can see from Figure 2, work under NREGA is available throughout the year, although it does dip during the Menseon months from July to-Oetober.

Writing about labor in rural Bihar is incomplete without an account of agricultural activity in rural Punjab. The existence of seasonal - and circular - migration from Bihar to Punjab during the paddy crop season has been pointed out by many authors (Sharma 1995, Rodgers and Rodgers 2001). The crop is sown during May, transplanted in June/ July, and harvested in October/November. ${ }^{15}$ Increasingly, however, their destinations are diversifying (Karan 2000, Sharma 2005, Rodgers and Rodgers 2009). A majority of my interlocutors in both the study Panchayats reported that they migrated to Delhi in the middle of April, ${ }^{16}$ to take up casual work in the construction industry. Some went to Rajasthan or western Uttar Pradesh. Then, when Punjab's paddy transplantation would begin - in June - some of them would make their way to that State from these locations.

\footnotetext{
${ }^{15}$ However, Rodgers and Rodgers $(1979,2009)$ note for their study villages in Purnea, a district that abuts Araria to the south, that migration peaked during winter and lasted up to April, the wheat harvesting season. In either case, it appears that the cultivation cycles in Punjab influenced - till recently - the seasonal patterns of migration from north Bihar.

${ }^{16}$ I happened to be in Sargana Panchayat in April 2010 and bade farewell to a group of nearly 30 men on the 15 th.
} 
Work under the NREGA picks up in November, which is the paddy harvest in both northwestern India and Bihar. This is interesting because clearly the paddy harvest season whether in Punjab or in Bihar - does not keep workers away from employment with the NREGA. This is also true of the patterns of NREGA employment in March/April, when the wheat crop is harvested in both northwestern India and north Bihar. Indeed, employment under the NREGA continues to rise through February, March and April. During these months, maize, rabi lentil, rapeseed and wheat crops are harvested. The employment generated under the NREGA during these three months together makes up 25-40 percent of the total employment across the three years. The availability of alternative employment opportunities evidently does not prevent workers from being attracted to the NREGA.

From Figure 2, it is clear that here too the NREGA projects were implemented without regard for the cropping cycle. Side by side, it appears that livelihood opportunities before agricultural laborers were compromised by the officials offering NREGA work during the cropping seasons. ${ }^{17}$ The official wage rate during my field work was 9 a day; laborers reported receiving between $\Omega$ and $\Omega$ per day. Frequent delay $\Omega$ payment were common, with the workers travng to laborers reported finding work for between 30 and 40 days in the village. Their timely deployment on farms was crucial for the transplantation of paddy saplings, the weeding operations for jute and the harvest of all crops. Each of the activities related to transplantation were remunerated at 30 per day, with an additional meal provided after the actual transplantation. Labcro employed during the paddy harvest were also involved in manual threshing and winnowing. Labor employed during the harvest was remunerated in a combination of cash and kind, along with daily provision of meals during their employment. Typically, payments were made entirely in kind, with a ninth of the harvest share being assigned to the entire group of laborers to divide up among themselves. No farmer or laborer spoke of cash payments made.

The jute crop was a labor-intensive cash crop in the locality. Laborers deployed during the weeding operations for the jute crop were paid betweer $\Omega$ and $\Omega$. The jute crop needed weeding interventions two times within a span of 13 crys: on first occasion, 80 laborers were required to weed jute crop grown over 1.5 bighas; on the second occasion, only 30 were needed. The harvest of the jute crop is an expensive proposition as well, and was remunerated in 2009 a per day (higher than the wages paid at the NREGA), along with a meal for the time they were engaged with the process.

In Table 5 I attempt to provide a comparative snapshot of the remuneration under the NREGA and agricultural work. Although the presence of in-kind payments to agricultural laborers makes it difficult to compare the two, it can be surmised that NREGA wages were only slightly higher than those paid for agricultural work. The 'in-kind' component of the agricultural wages met crucial, and immediate, household requirements even as it protected laborers from inflationary pressures. The time lag between the completion of the activity and the receipt of payments constituted a major difference between the NREGA and agricultural labor. Payments under the NREGA were frequently delayed, while most agriculturalists, on the other hand, made timely payments. At the same time, they were known to practice covert forms of untouchability against their laborers. Nevi Rishi told me once about a certain agriculturalist:

\footnotetext{
$\overline{{ }^{17} \text { During the months of October, December and January, for instance, there are no significant agricul- }}$ tural operations in the State. Yet few NREGA works were offered during that period in the four years under consideration.
} 
Table 5. Wage rates in Bihar. NREGA and agricultural wages compared.

\begin{tabular}{|c|c|c|c|c|}
\hline Month (1) & $\begin{array}{l}\text { Official NREGA } \\
\text { wage }\end{array}$ & $\stackrel{\text { Actual }}{\text { payment }} \Omega^{\beta}$ & $\begin{array}{l}\text { State-level prevailing } \\
\text { wages }\end{array}$ & $\begin{array}{c}\text { Locality- } \\
\text { specific wages } \\
\text { C }^{5)}\end{array}$ \\
\hline April 2009 & 89 & $50-60$ & $73 / 67$ (wheat harvest) & 45 \\
\hline July 2009 & 100 & $60-70$ & $\begin{array}{r}81 / 70 \text { (paddy } \\
\text { transplant) }\end{array}$ & $35-50$ \\
\hline September 2009 & 100 & $60-70$ & $85 / 76$ (jute harvest) & 70 \\
\hline November 2010 & 100 & $60-70$ & $83 / 78$ (paddy harvest) & 45 \\
\hline April 2010 & 100 & $60-70$ & 91/74 (wheat harvest) & 50 \\
\hline
\end{tabular}

Source: Column 2: Government of India (n.d. f).

Column 4: For April 2009: Government of India (2010, Table 12a); For July/November 2009: Government of India (2011c, Table 3a \& 7a); For April 2010: Government of India (2012b, Table 12a). Column 4 shows wages of men and women respectively.

Columns 3 and 5: Field notes and observations.

I was being served food in exactly the same plate every day: it had a scratch mark on its underside. I asked the lady of the house whether she had only plate in the house. She fumbled. I was the only harijan ${ }^{18}$ you see. I decided never to work on their farinm ever again. ${ }^{19}$

Despite the imperfections the NREGA and the incompetence of the attending officials, workers have embraced the program wherever it had been implemented. Admittedly, we are talking about less than 15 days in the entire year, for which work was being offered. But the practices of agricultural laborers in those 15 days - when laborers choose to engage with the NREGA and ignore the agriculturalists' farms - provide us with important insights into the transformations in the collective selves of some of eastern India's most impoverished denizens.

\subsection{What's going on}

That employment generated under the NREGA coincided with the cropping seasons in all the localities is clear from an analysis of the official data. While there are justifiably no formal prohibitions on NREGA work being carried out during the cropping seasons, it is intriguing that, given the well-known scarcity of work in rural areas, officials would have sought to provide the NREGA work in such a manner that laborers could work on both if they so wished. Nonetheless, while bureaucratic incompetence and ineptitude can explain why NREGA work was offered during the cropping seasons, they cannot explain the undertaking of this work by laborers despite the delays and corruption associated with it - all the more so when the majority of these work days overlapped with crucial cropping operations such as transplantation, weeding and harvesting, for which payments were relatively similar, predictable, assured and timely.

We could follow Herring and Edwards (1983), Williams et al. (2003) and Manor and Jenkins (forthcoming) in emphasizing the role of politicians in instigating demands by workers. However, such lines of enquiry pay too little attention to the meanings associated with the program among the rural poer, the laberers and the cultivaters of marginal size

\footnotetext{
$\overline{{ }^{18} \mathrm{~A} \text { term used by conservative political leaders to describe members of the so-called 'untouchable' com- }}$ munity. Most political activists prefer the term 'Dalit'. Obviously, however, Nevi Rishi's use of the conservative term does little to curtail the sense of anger he feels when confronted with discrimination.

${ }^{19}$ Hanging out, Sargana Ward 1 Musahar tola (West), 2 April 2010.
} 
plots who make up the bulk of the workers of NREGA projects. How is the program interpreted by its beneficiaries? What meanings do they attribute to it in relation to other streams of work? How do they 'feel' about the program? What collective identities are forged in relation to the program? What do these identities, meanings and feelings reveal about the rural workers' membership in the political community?

\subsubsection{Majhipur: seeking the state}

In Majhipur Panchayat's Rahimpur ward, ${ }^{20}$ I met with members of 14 of the 32 households that had ever received any work under the program. Here the narrative emerging from my interlocutors was that the NREGA helped them to connect with the state. One of the householders I interviewed was 40-year-old Arif Miya, who cultivated the aman crop on the two bighas of land he had leased in from a neighbor. During the 12 months prior to my conversations on the NREGA with him in February ${ }^{21}$ 2010, he had been engaged in many different employment streams. He and his wife Shefali had worked on an NREGA project to excavate a pond. This was in April 2009, for nine days. For this, they were paid $\rightarrow$ a day, slightly higher than the rates for harvesting operations. They worked for hours each day and received the payment nearly 20 days after they had completed the work. Arif Miya knew it was less than the stipulated wage, but was resigned to it.

A few weeks thereafter (May 2009), he and his sons ploughed their field in preparation for the aman crop. He would alternate work on the paddy field with daily commutes to Narayanpur, about six kilometers to the northwest, where he worked as a headloader for sand contractors supplying materials to the brick kilns of the vicinity. Here, he earned nearly (1) 0 a day, with payment being dispensed every evening after the completion of the cury's task. Once the Monsoons arrived, he, along with Shefali and his sons, got busy preparing for the transplantation of the saplings. He went back to construction work and brick kiln operations in Narayanpur and Maldah when these resumed after the Monsoon season. He was paid between 0 and 120 per day when he worked in the construction sector as a daily laborer for 15 crays. In December, he harvested his crop, a fourth of which was collected by the landlord as the legally stipulated rent. He sold the remainder of the crop to the contractor who came to the village to collect the harvest. After concluding the sale, Arif Miya left for Ranchi for a 50-day stint in a brick kiln there. Here he was paiß $\longrightarrow 0$ a day, along with housing and food. Shefali stayed back. Arif Miyan returned jurs the week prior to our meeting, in January 2010, and was back to working intermittently in Maldah town. By the second week of February, Shefali and he were working on a 12day NREGA project.

Over the last year, as the above account clarifies, neither Arif nor his wife had hired out their labor to other agriculturalists. They had kept away from those farms during the boro transplantation and harvest seasons, even though they had no cultivation of their own to attend to. They had taken up work on the NREGA projects during the boro harvest in April 2009. During the boro transplantation in February 2009, Arif was doing the daily commute to Narayanpur and Maldah, where he worked over ten hours, leaving at 5 in the morning and returning at about 7 in the evening. I hung out with him and his friends

\footnotetext{
${ }^{20}$ I lived in Rahimpur from 10 December 2009 to 17 December 2009, and again from 1 February 2010 to 14 February 2010.

${ }^{21}$ I first met him on 3 February; interviews and 'hanging out' with neighbours and co-workers till 10 February.
} 
each morning during the first week of February. I was with them at the chai kiosk we frequented, and heard him plan his day and week. When I asked him whether agricultural work was better than the work he did in the towns, he laughed sardonically: 'One ruins the lower back, while the other ruins the upper back. They both kill. ${ }^{22}$ Arif's daily earnings in the town far outstripped the wages he would receive for transplanting saplings or doing other agricultural work. But they were also far in excess of NREGA wages. It was interesting that Arif took up NREGA work instead of the better-paying work in Maldah and Narayanpur.

The chai kiosk was patronized mostly by wage laborers commuting daily to Maldah town and Narayanpur: they would crowd in by 4 a.m., and leave for their destinations within an hour. Through the first week of February, Rahimpur's agriculturalists would approach the laborers at the kiosk, trying to persuade them to help out with the transplantation of the boro saplings. Arif Miya and his friends would sit expressionlessly when the agriculturalists came by. On most of the mornings I spent in that kiosk, there were at least 27 laborers who were doing the commute ${ }^{23}$ to Naraynpur and Maldah town. Hardly any of them responded favorably to agriculturalists' requests. During the last few days of my stay in the village, however, the numbers had depleted considerably and I observed no more than 15 laborers each day. Like Arif, they had all opted for the NREGA project, and were in no hurry for their morning chai. What was it that led Arif and the others to prioritize the NREGA over Narayanpur's better-paying brick kilns and agriculturalists' timely-paying cropping operations?

Arif Miya's co-workers suggested that engaging with the NREGA connected them with the government directly. The program reinforced their understanding of the government as an agency that could help them lead better lives. Engagement with a 'government program' helped them demonstrate to other villagers that they too could benefit from the state's attention, and that the state did 'care' for them. Ironically, even as the government tried to portray the workers engaged with this project as those seeking a wage, Arif Miya and his co-workers appear to seek the state through their employment with the NREGA. They 'see the state', to borrow from Corbridge et al.'s (2005) evocative phrase, as a multifaceted entity, and the NREGA represents a facet that is more favorable than what they have usually seen. As beneficiaries of the state's care, they are able to ignore claims on their labor by local agriculturalists. Their labor is reserved for use as they think apt, not to be determined by the agriculturalists.

Arif Miya and Shefali Bibi worked for slightly over 200 days ${ }^{24}$ between the two years. Table 6 provides incomplete details about their work and incomes. But it is clear that the couple were employed on the NREGA for 24 days throughout the year. During that period, different cropping operations were going on in their village, as well as industrial activities in the vicinity of their village. They chose to work on the NREGA despite these alternatives, which would have both been advantageous, as we have seen. However, working on the government program allows them to withdraw from the reserve army of labor upon which local agriculturalists and industrialists think they can draw with impunity.

\footnotetext{
${ }^{22}$ Hanging out, Ghandy's chai kiosk, Rahimpur, 6 February 2010.

${ }^{23}$ This was only one of the four kiosks in the village (and the one preferred by laborers because the chai cost the least here).

${ }^{24}$ This data is to be considered alongside Guha's (1996) warning that labor days should not be counted as homogeneous.
} 


\begin{tabular}{|c|c|c|}
\hline Work stream & $\begin{array}{c}\text { Season/No. of } \\
\text { days }\end{array}$ & Remuneration \\
\hline $\begin{array}{l}\text { Construction work, } \\
\text { Gurgaon mall (AM) }\end{array}$ & $\begin{array}{l}\text { February/ } \\
\text { March } 50 \text { days }\end{array}$ & $\begin{array}{l}\text { 10-12 hour workday, carrying } \\
\text { heavy weights, laying bricks, } \\
\text { carrying cement }\end{array}$ \\
\hline NREGA $(\mathrm{AM}+\mathrm{SB})$ & $\begin{array}{l}\text { April } 9 \text { days } \\
\text { (X2) }\end{array}$ & $\begin{array}{l}\text { Eight hours per day, digging } \\
\text { earth, laying laterite road '60 } \\
\text { per day. } \\
\text { Alternative employment: } \\
\text { Boro Harvest }\end{array}$ \\
\hline $\begin{array}{l}\text { Paddy sowing (AM } \\
+\mathrm{SB})\end{array}$ & $\begin{array}{l}\text { June } 10 \text { days } \\
\text { (X2) }\end{array}$ & $\begin{array}{l}\text { Four hours (?) per day prepare } \\
\text { soil, spread seeds, look out for } \\
\text { weeds }\end{array}$ \\
\hline Brick kilns (AM) & June 15 days & $\begin{array}{l}\text { Carrying loads of up to } 10 \mathrm{~kg} \\
\text { on the head/back for distances } \\
\text { (about } 200 \text { metres). Ten hours }\end{array}$ \\
\hline $\begin{array}{l}\text { Paddy } \\
\text { transplantation (AM } \\
+\mathrm{SB})\end{array}$ & $\begin{array}{l}\text { July/August } \\
6 \text { days (X2) }\end{array}$ & $\begin{array}{l}\text { One 4-hour shift, prepare aisles } \\
\text { of mud, bundles of saplings, } \\
\text { pluck saplings, sow saplings. } \\
\text { Standing in puddle, bent waist- } \\
\text { downwards }\end{array}$ \\
\hline $\begin{array}{l}\text { Construction work } \\
\text { (AM) }\end{array}$ & $\begin{array}{l}\text { September } \\
15 \text { days }\end{array}$ & $\begin{array}{l}\text { Laying bricks, lifting them, } \\
\text { carrying cement and other } \\
\text { manual labor. Ten hours. }\end{array}$ \\
\hline Paddy harvest (AM) & $\begin{array}{l}\text { December } \\
6 \text { days }(\mathrm{X} 2)\end{array}$ & $\begin{array}{l}\text { Ten hours per day. Harvesting, } \\
\text { manual threshing, winnowing, } \\
\text { making bundles, selling to } \\
\text { paykar (market contractor) }\end{array}$ \\
\hline $\begin{array}{l}\text { Brick kilns, Ranchi } \\
\text { (AM) }\end{array}$ & $\begin{array}{l}\text { December- } \\
\text { January } \\
50 \text { days }\end{array}$ & $\begin{array}{l}\text { 12-14 hours. Carrying loads of } \\
\text { up to } 10 \mathrm{~kg} \text { on the head/back } \\
\text { for distances (about } 200 \\
\text { metres). Living in open air, pravel, } \\
\text { sitting crouched for long hours, } \\
\text { carrying heavy weights, } \\
\text { working near ovens. }\end{array}$ \\
\hline NREGA $(A M+S B)$ & $\begin{array}{l}\text { February } \\
12 \text { days }(X 2)\end{array}$ & $\begin{array}{l}\text { Eight hours per day, digging } \\
\text { earth, laying laterite road } \\
\begin{array}{l}\text { Alternative employment: boro } \\
\text { transplantation }\end{array}\end{array}$ \\
\hline Total & $\begin{array}{l}204 \text { days } \\
\text { between AM } \\
\text { and SB }\end{array}$ & \\
\hline
\end{tabular}

Source: field notes. $\mathrm{AM}=$ Arif Miya, $\mathrm{SB}=$ Shefali Bibi. 


\subsubsection{Sargana: pursuing dignified lives}

In Sargana's Ward $1,{ }^{25}$ I met members of all 17 families that had received work under the program over the previous year. For them, the program appeared to be a means of asserting their dignity. In the first of many conversations (18 March 2010), 40-year-old Maturi Rishi, who owned no land and usually worked as an agricultural laborer in the village, elaborated on this. During March and April 2009, he, his wife Saijani and his family members had all worked on the maize and then the wheat harvest. They had received in-kind payments. On both occasions, as laborers, they had received one-ninth of the produce (Maturi calculated the monetary value of their wage to be abou per person for each of the 12 days they had been engaged in these operations) to be di up among themselves. Further, they were allowed - by custom - to keep the husk of the maize crop for use as fuel. But he also added that there had been no NREGA work offered during that period. His brother suggested that they might have taken up working on an NREGA project had it been introduced during that period.

Once the harvest season was over, Maturi and a group of laborers headed towards northwestern India as they did each year. He had spent a total of six months outside the village. Of these, three months were in Punjab, split between two trips. One trip was with a group of workers that traveled to Punjab for transplanting the paddy saplings (June/July). Another was to harvest them (October). For the remaining three months, he was in Alwar and Delhi: in Alwar (May/June) he was employed in brick kilns, while in Delhi he worked as a construction laborer (September). In each of these places, he received between ${ }^{0}$ an $\bigcirc 0$ per day. All payments were in cash and made on a daily basis.

2 he meantime, Saijani worked with six other women from her hamlets to transplant paddy saplings for 10 agriculturalists. They worked for five days, and received payment in cash. He recalled that they had to haggle with the farmer on the last day, although eventually all their dues were cleared. The payments comprise $\bigcirc$ per day for each of the fields they transplanted as well as a meal comprising rices piece of gourd and lentil soup. Later in September, she and her sister-in-law had worked on the jute harvest. They had each received the equivalent o $\bigcirc$ per day, as well as the husk of the jute crop, which was invaluable as fuel.

Maturi returned in October 2009 after the Punjab paddy harvests were completed. The following month, the paddy crop was harvested locally. Maturi recalled being reluctant to work on the harvesting operations because of the whimsical attitude of the agriculturalists. Saijani was even less keen to work on the operations, he said, because of the way the agriculturalists' wives scorned her for allegedly emulating them by wearing sarees instead of the ghagharas that were associated with their community. Nevertheless, they both worked, in a group of 12, for an agriculturalist, who remunerated them with, as before, one-ninth of the harvest. Maturi Rishi calculated that the cash value of what they received was abou $\bigcirc$ per day per person.

When EGA employment was offered in January 2010, Maturi, along with eight other men and women in his hamlet, came to work on the program. They worked for four days, at which time the project was declared complete. They were pais $\Omega$ for each day, but had to wait nearly a month. Much quarreling with the bureaucrats sponsible for timely disbursal of payments marked the time between the completion of the

\footnotetext{
${ }^{25}$ I lived in Sargana from 8 to 30 January 2010, and again from 14 March to 17 April 2010. My residence in Sargana was adjacent to Roshanar Gram Panchayat, allowing me to access this Panchayat eenveniently.
} 
program and the final disbursal of the wages. In March 2010, just before our meeting, work on another project had been introduced. Despite the bitter experience of the previous time, Maturi Rishi and four members of his extended family sought work under the program. This time, they had worked on it for nine days at a stretch. Saijani and other members of his extended family told me they were pleased that they no longer needed to work for the agriculturalists. They did not have to bend to anyone's orders, they said. Maturi's uncle, 53year-old Shanichar Rishi, agreed with his nephew that the program, despite its messiness, had done a lot of good to workers (bahut bhala hua). He continued, 'Thanks to this program, at least we don't have to dance to other people's tunes in the village'. ${ }^{26}$

During the many evenings I spent in Maturi's neighborhood, I observed many agriculturalists coming to request labor to help with their maize and wheat harvest operations. Unfailingly, the residents of the hamlet would offer the visitors chai. They would refuse. There would be some general conversation. The visitors would make their request. They would be ignored. My interlocutors in the hamlet tried to assure me that they did agree to many requests, and that they had nothing against farmers in general. It was just specific farmers that they did not want to work with, they said. They were willing to work with farmers who respected them ('hamari ijjat karte hain'), but not with those who insisted on calling them by their caste names. One evening, 51-year-old Bhukhan Rishi lost his patience with my relentless inquiries about how they decided who to work for:

Did you see how many people accepted our offer of chai? Is this the way to treat us, when we have been so hospitable? Just because they consider us untouchable? Tell me, if this is the way they treated you where you live, would you ever work for them? ${ }^{27}$

Bhukhan Rishi's comments nailed the issue for me. By asking me whether I would work in the circumstances to which he and others in his community were subjected, he exemplified what they had been saying about them intending to lead lives in accordance with notions of dignity. His outburst suggests an impulse among agricultural laborers to turn away from economic relations that are embedded in hierarchical social relations. It points to the claims of social equality that are important to my interlocutors in Sargana and the denial of those claims by the locality's agriculturalists. ${ }^{28}$

Each of my eight interlocutors that evening had worked on the NREGA projects that were ongoing during that time, and on which Maturi Rishi and his family had been employed. A few days after Bhukhan Rishi's outburst, I made another faux pas by asking if they preferred the NREGA because they earned more than they would if they worked on the cultivators' lands. Bhukhan disagreed vigorously:

... we earn more in Punjab, don't you understand? Why are we here when we can earn more there ... Tell me ... With the narega, we can live in the village without having to adhere to its habits. ${ }^{29}$

\footnotetext{
${ }^{26}$ Hanging out, Musahar tola (West) machan, Sargana Ward 1, 23 March 2010.

${ }^{27}$ Hanging out, Musahar tola (West) machan, Sargana Ward 1, 2 April 2010.

${ }^{28}$ That the agriculturalists had been at the forefront of the emancipatory struggles which had politicized questions of social equality and dignity (Frankel 1989, Roy 2013, Witsoe 2013) was not lost on my interlocutors. But there was a sense of betrayal when the agriculturalists persisted with socially treating them as 'untouchable'.

${ }^{29}$ Hanging out, Musahar tola (West) machan, Sargana Ward 1, April 4, 2010.
} 
It is pertinent to note that migration to Punjab and Haryana continues to remunerate better than either NREGA work or local farm work. Migrants to Punjab reported receivin $\Omega 0$ per day on average. In Delhi they earned, on average 0 per day. By contrast, NKLUA work paid them onl $Q$ in 2009-10. Although farm ges were slightly lower than NREGA remuneration (2 exceptions such as the jute harvest), the in-kind nature of some payments was valued, especially by the women among my interlocutors. Had higher incomes been the only motivating factor, Sargana's villagers would be thronging to the cities and striving to stay there. However, migration remains short-term. Most migrants stay away for four to six months at a stretch, while others return within three months, stay home for a couple of months and then go back for another three months. ${ }^{30}$

Maturi Rishi and his wife Saijani worked for 174 days through the period from February 2009 and February 2010. Table 7 provides some details about their engagements with the world of remunerated work. Of these 174 days, they worked on NREGA for 26 days. During those 26 days, there were other cropping operations ongoing as well. Although not always as well remunerated as the NREGA, they did offer several advantages. But neither Maturi nor his wife opted for any of those when they could work on this program. The value of the NREGA appears indeed to stem from the fact that laborers could live and work in the village without adhering to its habits. These habits included as we have seen - caste-based discrimination and the servility associated with it. They included an expectation that agricultural laborers would be on call for agriculturalists, but would quietly retreat into their homes or hamlets when not needed. It was the expectation to serve in a reserve army of labor that engagement with the NREGA allowed them to flout.

\section{Survival, everyday resistance or encroachments?}

How are we to theorize the phenomenon of rural workers, among the most impoverished segments of India's population, choosing to work on the NREGA during those times of the year when their labor is needed for agricultural operations? How are we to explain the phenomenon of rural workers eschewing the social identities as members of a reserve army of labor for agriculturalists that has been imposed upon them? It is one thing for labor shortages to be the result of outmigration. It is quite another for labor shortage to arise when potential laborers are present in the villages, but opting for other employment opportunities. Admittedly, we are only talking about 20-30 days in the entire year. But these overlap with some of the most crucial aspects of cropping operations. They have to be analyzed as constituting a political act, for reasons that I lay out in this section.

\subsection{NREGA and the coping poor?}

It is tempting to suggest that workers' engagement with the NREGA reflects nothing more than a coping strategy. Samuel Popkin (1977) famously characterized the peasant as a rational being, with the same motivations, interests and preferences as anyone else. What holds good for the 'peasant', one could argue, holds true for the rural proletariat as well. They are motivated by a desire to cope with their livelihood insecurities and choose to

\footnotetext{
$\overline{{ }^{30} \text { There had been a few instances of permanent migration among the wealthier households in the }}$ village, but none from this conspicuously impoverished hamlet.
} 
7. Workdays, Maturi Rishi and Saijani Devi, February 2009-February 2010.

\begin{tabular}{ll} 
Work stream & $\begin{array}{l}\text { Season/No } \\
\text { days }\end{array}$ \\
\hline $\begin{array}{l}\text { Wheat/maize harvest } \\
\text { (SD) }\end{array}$ & $\begin{array}{l}\text { March/Apr } \\
12 \text { days }\end{array}$ \\
& \\
$\begin{array}{l}\text { Brick kilns, Alwar } \\
\text { (MR) }\end{array}$ & May 35 da \\
& \\
$\begin{array}{l}\text { Paddy } \\
\text { transplantation, } \\
\text { Punjab (MR) }\end{array}$ & $\begin{array}{l}\text { June/July } \\
\text { 20 days }\end{array}$
\end{tabular}

Paddy transplantation June/July Local (SD)

Jute harvest

Local (SD)

Construction work, housing complex Delhi (MR)

Paddy harvest Punjab (MR)

Paddy harvest Local (MR) 9 days 20 days

October 16 days 16 days
Activities $\quad$ Remuneration

Work in agricultural farms. In-kind. One-ninth of Barefoot. Cut crops with sickles and other basic implements.

produce, calculated per day. No meals pr d. Could keep maize and wheat husk.<smiles>C1=C[C@@H]2CC[C@H]12</smiles>

September

September

November
12-14 hour workday, open air, sitting crouched for long hours, carrying heavy weights, work near ovens

One 4-hour shift, prepare aisles of mud, bundles of saplings, pluck saplings, sow saplings. Standing in puddle, bent waistdownwards

One 4-hour shift, prepare aisles of mud, bundles of saplings, pluck saplings, sow saplings. Standing in puddle, bent waistdownwards

Work in agricultural farms. Barefoot. Cut crops with sickles and other basic implements. Tear the cover and pile up the crop neatly

Laying bricks, lifting them, carrying cement and other manual labor. Ten hours.

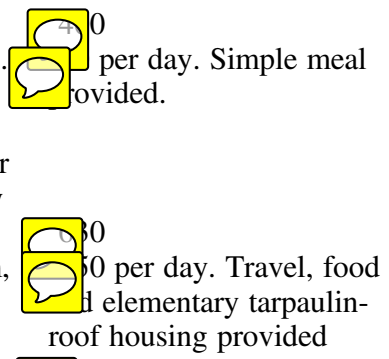
0 per day. Travel, food t elementary tarpaulinroof housing provided 20 ovided.

Ten hours per day. Harvesting, manual<smiles>C1CCC2CCCC2C1</smiles>
0 per day. Travel, food ilementary tarpaulineroof housing provided
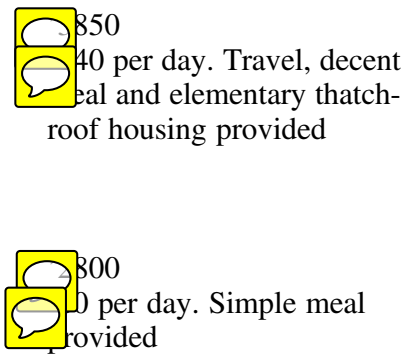
threshing, winnowing, making bundles of the crop

Ten hours per day. Harvesting, manual threshing, winnowing, making bundles of the crop per day. Decent meal

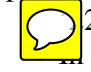
240 kind payment of oneninth of the harvest, calculated at per day. Simple meal 
Table 7. Continued.

\begin{tabular}{lll}
\hline Work stream & $\begin{array}{l}\text { Season/No. of } \\
\text { days }\end{array}$ & Activities \\
\hline $\begin{array}{l}\text { NREGA } \\
\text { (MR + SD) }\end{array}$ & $\begin{array}{l}\text { January } \\
4 \text { days (X2) }\end{array}$ & $\begin{array}{l}\text { Eight hours per day, digging } \\
\text { earth, laying laterite road } \\
\text { '60 per day. } \\
\text { NREGA }\end{array}$ \\
$\begin{array}{l}\text { Fight hours per day, digging } \\
\text { (MR + SD) }\end{array}$ & $\begin{array}{l}\text { earth, laying laterite road } \\
\text { Alternative employment: } \\
\text { wheat harvest }\end{array}$ \\
Total & $\begin{array}{l}\text { 174 days } \\
\text { between MR } \\
\text { and SR }\end{array}$ &
\end{tabular}

Source: field notes. $\mathrm{SD}=$ Saijani Devi, $\mathrm{MR}=$ Maturi Rishi.

work on a program that pays them better than others. Applying this perspective to the NREGA, it is true that the program pays them better in comparison with agriculture. Admittedly, it pays them only slightly more, but one could argue that for impoverished households, what appears to middle-class analysts to be slight means a lot. Furthermore, one might say, it pays in cash, which potentially offers households greater choice while making purchases.

However, if increasing incomes were the only motivation for laborers, it is unclear why they do not migrate to cities where there are far greater opportunities for work, and at higher rates of remuneration. Moreover, as we have seen, the economic significance of agricultural labor should not be underestimated either. Farm work, when remunerated in kind, protects laborers from inflationary pressures. Also, food and fuel needs are met immediately. When remuneration is in cash, it is paid immediately after the completion of the task. This is crucial for laborers who often need cash on an immediate basis. Livelihood insecurities stem not only from low cash incomes, but also the lack of availability of other basic necessities such as food and fuel: delayed, and less-than-expected, cash payments are hardly likely to meet these necessities in a timely way.

I have shown that rural laborers ignore available farm opportunities, despite the obvious benefits accruing from the immediate in-kind nature of the wages accruing from it. On the other hand, the monetary benefits from the NREGA are usually delayed and arbitrary on account of bureaucratic ineptitude and corruption. The argument that the NREGA is a strategy through which the poor cope with their livelihood constraints, and use it to enhance their incomes, does not appear very sustainable. Indeed, rural workers face several vicissitudes when it comes to receiving their wages. Given these vicissitudes, it is a wonder that people engage at all with the program.

\subsection{NREGA as a vehicle of resistance?}

While rejecting the rubric of 'the coping poor' to examine the engagement of rural workers with the NREGA, it is important not to swing to the other extreme, as indeed I was tempted to more than once during my fieldwork. In emphasizing the political and collective dimension of workers' lives, it is also easy to offer the perspective that workers are engaged in 'resistance'. Their acts of opting for NREGA work over agricultural labor lend themselves to interpretations that they are 'resisting' the power and authority of local elites and their claims over workers' labor. It would seem that the risks they take in ignoring the calls 
by farmers to work on their fields could not have been but calculated and not absentminded. In doing so, it would further appear agricultural laborers were resurrecting a hoary past of resistance to domination and subjugation.

An important contribution to understanding how rural populations 'resist' social authority in quotidian ways without attracting too much attention comes from the work of James Scott (1985). In his able hands, the notion of 'everyday resistance' was formulated to emphasize the political significance of oral exchanges, peasants' private characterizations of their superiors, pilferage, sabotage and evasions. Much of the work under this rubric has tended to focus on 'subtle, indirect, and non-confrontational behavior' (Kerkvliet 2009, 233). At first glance, Scott's work appears to be apposite to the dynamics I am analyzing.

However, it is not. Among the most important criticisms of the notion of 'everyday resistance' is - as C.P. White puts it - 'its focus on negative manifestations of power rather than the question of how peasants can exercise positive political power' (White 1986, 50). Indeed, Scott's conceptualization of human agency tends to focus more on the ability to adapt than to the ability to transform (Gutmann 1993, 86). There is little to be said in this framework about the ways in which the 'peasant' or the 'rural proletariat' might imagine political transformation. Although Scott's work does discuss the infringements and transgressions that allow peasants to conform their social oppressors, much of his analytical attention focuses on 'evasion' (Scott 2011) as a tactic of the powerless. Sociologist Asef Bayat argues that the notion of 'everyday resistance' restricts analytical attention to people defending what they have, rather than making fresh demands (Bayat 2010, 54, italics added).

In Sargana, I enthusiastically asked my interlocutors in Maturi Rishi's hamlet whether they thought the program was a way of 'resisting' oppression ('julam ka muqabla') by agriculturalists. At this, my interlocutors looked puzzled; it was Bhukhan Rishi again who broke the silence: 'Why should I do sangharsh against him. The agriculturalist can go to hell (Bhaadh mein jawe kisan)'. Bhukhan Rishi's remark that 'the agriculturalists can go to hell' does not appear calculated to undermine the agriculturalists' economy. While agricultural laborers detested farmers' pretensions and practices of untouchability, they did not focus their energies and strategies against them, or even on them.

Analytically, a reading of the workers' decisions to opt for employment under the NREGA as 'everyday resistance' to agriculturalists continues to privilege agriculturalists as the focus of attention for the putative resistors. It enforces a view that the laborers take the agriculturalists' claims and requests seriously, and calculate their moves against them. Viewing the workers' engagement with the NREGA as aimed at the agrarian economy confers on this economy precisely the importance that the workers themselves are trying to deny it. In other words, and somewhat paradoxically, the obsession with resistance suggests that agricultural workers are impelled to resistance, thereby reducing their ability and intention of charting their own destinies. It identifies antagonists that workers disregard as antagonists worthy of attention.

In Rahimpur, I was witness ${ }^{31}$ to a fascinating exchange between women agricultural laborers from the Munda community, natives of the nearby Habibpur block, transplanting the boro crop on the field of an agriculturalist, a Shershabadiya Muslim. The laborers and the agriculturalist were working side by side when I went to interview the latter. The laborers claimed they were pai $\bigcirc$ for the four hours they spent transplanting 100 saplings on two bighas of land: this cld was not contradicted by their employer, who was within earshot.

\footnotetext{
${ }^{31} 4$ February 2010. Hanging out at Manhir ul Islam's paddy field.
} 
In between giggles, they said, 'When the Mahajan [a local term for employer] has to work so hard, what do you expect to happen to us poor people'. After some more jovial banter, they then turned to the agriculturalist and one told him, still giggling, 'You better start paying us more or you'll find us at the ek sho deener kaajer sthol (NREGA worksite)'. And another quipped, 'Actually, you should also join us. I have a brother-in-law as the supervisor. He'll get you a job'. The farmer sheepishly grinned, and said, 'Yes bowdi (elder brother's wife), ${ }^{32}$ please ask him to get me a job on the site. Any job will do, including looking after your babies!'

It is possible that these very same agricultural laborers did indeed take up NREGA work as it was offered during the following season, with all the delays and difficulties it entailed. If they did, can their taking up work be analyzed as resistance to farmers like the one with whom the agricultural laborers engaged in jovial banter? Could it even be called 'everyday resistance' when the laborers are not inhibited at all in the presence of their employers? ${ }^{33}$ To analyze their decision to take up employment under the NREGA as 'resistance' to agriculturalists like the one mentioned above would leave the term 'resistance' bereft of any meaning.

The 'everyday resistance' paradigm tends to impose an essentialized identity on putative resistors. Resistant subjects are seen as protecting their way of life, seeking autonomy from aggrandizing elites, and evading the framework of the state. The only ideas of life they seem to have are what they have inherited. An analysis of the practices of agricultural laborers in relation to the NREGA and their associated interpretations of it shows that exploited and subordinated people do indeed harbor ideas of transformation, anchored in notions of security and dignity. They strive to make things better for themselves, their families and their descendants, rather than merely increase their incomes or seek wages. I am therefore constrained to look beyond the framework of 'resistance' - everyday or spectacular - to examine the dynamics that I presented earlier.

\subsection{NREGA as dignified encroachments}

In my reading, then, the engagements of rural workers with the NREGA represent neither 'rational coping' strategies not tactics of 'everyday resistance'. These engagements possess an unstable and inherently contradictory quality to which flattened characterizations do no analytical justice. I contend that their actions are more usefully described as a series of 'encroachments'. I build my approach on, but also sharply distinguish it from, Asef Bayat's notion of 'quiet encroachments'. Bayat highlights the 'silent, protracted but pervasive advancement of the ordinary people on the propertied and powerful, in order to survive and improve their lives' (Bayat 2000, 545). Quiet encroachments are characterized by the individualized concurrent attempts by a number of individuals to advance their shared interests, marked by episodic collective action, which takes the form of open and fleeting struggles without clear leadership, ideology or structured organization. In his more recent work, Bayat introduces the concept of social nonmovement to refer to "collective actions of noncollective actors; they embody shared practices of large numbers of ordinary

\footnotetext{
${ }^{32}$ This use of fictive kinship is rather interesting. While it is usual for employees to invoke such relations vis-à-vis their employers, it is much less common for employers to address their employees in such respectful terms. This term was very commonly used by the Muslim agriculturalists to refer to their Munda laborers in Rahimpur.

${ }^{33}$ Hart (1991) alerts us to the ways in which women laborers were able to relate to their employers and other influential people in far more antagonistic ways than their male counterparts did. The evidence here seems to be exactly the opposite.
} 
people whose fragmented but similar activities trigger much social change...' (Bayat 2010, 14).

Bayat's formulation steers clear of the defensive connotations invoked by 'everyday resistance'. He emphasizes the agency of the urban poor in Cairo and Teheran in trying to improve the quality of their life, often placing themselves at odds with the state and with other elites. By emphasizing advancement over notions of autonomy, protection and evasion, Bayat's work helps us to think of the politics of assertions in public spaces, assertions that often lead to consternation among elites. That hundreds of thousands of people in each of the States discussed in this paper engaged with the program imbues these engagements with a collective character, even when these were uncoordinated.

By taking up employment with the NREGA rather than work on the cropping operations of the local agriculturalists, erstwhile agricultural laborers assert their presence in the village, without having to adhere to the customary relations of subordination and social hierarchies. Theirs is a public presence - neither hidden nor subtle. They make their way publicly to the worksites in groups of eight to 10 workers. Their worksites are usually public land. They receive their wages in public, by public authorities. When a dispute arises, that is also public.

Their disregard for the fate of the agrarian economy is thus publicly demonstrated. They ignore requests by agriculturalists to labor on their land. Their indifference to the social customs and traditions of the village is pronounced. This indifference is actively cultivated, rather than absent-minded. It is cultivated in order to enable workers to lead better lives. It displaces the local agriculturalists from the positions of prominence they have assumed in the local polity. And it does so publicly.

This public presence constitutes a series of encroachments. Although encroachments are usually associated with breaking formal laws, I would like to emphasize their social dimension. In particular, I am thinking of the manner in which social norms, habits and ways of thinking in the villages are infringed upon by workers' engagement with the NREGA. They are present in the village, but they do not do what they are supposed to be doing. They are not supplicating before agriculturalists to give them work. Indeed, they are not even supplicating officials for work. If no work is forthcoming, they migrate. The inculcation of indifference through alternative public presence has ruptured the social behavior expected of them. It reflects an attempt by them to lead lives that accord with their emerging political imagination and collective self-making, where they are not subordinate to social elites, and are able to connect with the state on their own terms. People like Saijani Rishi and Shefali Bibi seek to assert their place in the village public as equals. One the one hand, they and their husbands refuse to conform to the roles imposed upon them, particularly the role of serving others. They desist from being recruited as 'reserve labor' for agriculturalists, to be on call whenever required of them. On the other hand, they occupy public spaces and assert their presence therein. The political imagination that animates their encroachments is one of social transformation rather than a preservation of the status quo.

The labor shortages that agriculturalists face are not novel. These shortages have been caused by the exit of agricultural laborers to other destinations. Workers are absent from the village, and being absent, they cannot possibly work on the fields. Their absence enables their erasure from the social landscape. They do not break any social expectations, as they are seen to be pursuing better income opportunities.

However, the engagement of people like Arif and Maturi with the NREGA changes that position. They are present in the village but their identifications are different from the customary roles that were imposed upon them. Their decision to stay in the village and take up employment under the NREGA represents an encroachment on the assumption that landless laborers 
have only two choices: either to work the fields of agriculturalists or to exit the village altogether. ${ }^{34}$ Rural workers encroach upon socially authorized relations of subordinati

These encroachments on a way of life that had long been thought to be the social are resented by agriculturalists. Agriculturalists referred derisively to the infiltration of new ideas, the alleged pampering of the lazy by the state and the perceived insolence of the laborers. During my fieldwork, it was common for them to revile their erstwhile agricultural laborers as stepping beyond their limits (aukat se bahar) and being impertinent ( $k i$ asphorda). However, as I have emphasized, the laborers did not intend to do any of this. They sought employment under the NREGA to make things better for themselves and their families. That these actions undermined the social meanings and authorities associated with rural living was an unintended consequence. This resonates with C.P. White's (1986) contention that what is often resistance (everyday or otherwise) may not have been intended to be that. The label of 'resistance' is an identity imposed by elites. Bayat's formulation of encroachment reiterates this important point: the act that constitutes an encroachment is not intended to infringe or transgress. He says that the intention of the encroachment is to facilitate survival and improvement.

At this stage, however, I am compelled to confront a fundamental problem with Bayat's formulation: his preoccupation with people's survival and with them improving their lives. Although he takes great pains to assert that his subjects are distinct from the coping poor, he could do more to analytically clarify the extent to which the poor are willing to go in order to improve their lives. Bayat does tell us that his encroaching subjects make claims on those with authority, influence and resources - not on one another. I completely take on board this insight: the encroachments I have referred to are always at the cost of the privilege, status and profits of those wielding influence and control in the rural polity. However, even this leaves too many possibilities open. Do all claims on social elites intended to improve lives constitute an encroachment? For instance, does stealing from the wealthy, and keeping the proceeds for oneself (unlike the social bandits described by Hobsbawm 1959), constitute an encroachment? My intention in raising this question is not to enter into a debate on the morality or otherwise of stealing, but to problematize what appears to me to be an excessive focus on 'improvement' in Bayat's formulations.

My discontent stems from the genealogy of 'improvement', as an analytical trope, in Utilitarian writings. Asa Briggs (1959) reminds us that Utilitarian ideas of 'improvement' emphasized efficiency and a self-centered calculative rationality that is only mindful of benefits. A singular possibility inheres in the notion of 'improvement', with alternatives deemed sub-optimal. It is this singularity with which I am uncomfortable. As the reflections of my interlocutors above show, the livelihood choices exercised by rural workers are informed by motivations that cannot always be reduced to the motivation of attaining 'improvement', efficiency and a self-centered calculative rationality. The workers did not want to take up just about any job or employment that might 'improve' their incomes. Rather, the pursuit of a secure and dignified life animated their concerns. There is little doubt that they wanted to make a change from their existing circumstances. But they wanted to do so honorably. ${ }^{35}$

\footnotetext{
${ }^{34}$ It is true that there is an emerging category of households benefitting from rural non-farm livelihoods: indeed, the proportion of such households in a district such as Maldah rose from 4 percent in 1991 to 16 percent in 2001 (Government of West Bengal 2007, 98). But by their very nature, these activities are not of a public type, being conducted from their homes.

${ }^{35}$ In following an amended approach to the notion of 'encroachment', I am mindful of the fact that workers' engagement with the NREGA is within the legal remit. It is a program implemented by
} 
The solidarities around the worksite allow us to think about the relationship of the workers with the state as well as what this implies for their membership in the political community. Although there is little sense of NREGA as a 'right' (the program is simply called narega in Bihar and 'hundred days' work' in Bangla), there was no doubt among my interlocutors that this was a program implemented by the state for the rural poor. The government should have implemented such a program a long time ago, was the refrain. It is the government's responsibility to ensure that we didn't suffer, was another widely shared belief. I am unsure as to whether it would be appropriate or even desirable to subsume the affective and interpretive insights offered by my interlocutors under the analytic rubric of citizenship in its juridical and social form. That discussion is beyond the scope of the present endeavor. What is clear is that workers' engagement with the program certainly contributed to the forging of a political community. These encroachments into social customs, behaviors and habits substantiated their membership in the political community with an assertive content. They reflected the urge among rural workers to live in the village without being subordinated to hierarchical social relations.

An initial coalescing of diverse members of the rural proletariat - the landless laborers, the sharecroppers and those holding marginal-sized plots of land - around the program is discernible. When Arif Miya and his friends say that the NREGA is for 'people like us', or when Shanichar Rishi remarks that 'we don't have to dance to other people's tunes', they are contributing to the forging of a shared community of proletarianized - and proletarianizing - workers. As with their workplaces in the cities, the NREGA worksite is a space for generating collective identities among people facing or enveloped by economic marginalization and social discrimination. This engagement builds on existing socialities based on neighborhood, ascriptive identity and economic circumstance. On the fields of agriculturalists, such socialities had been mediated by them and controlled by their supervision. At the NREGA worksite, however, levels of surveillance and discipline are more relaxed. Here, an occasional slackness goes relatively unreported. This incipient formation of a collective identity around the political spaces of work is unmistakable.

\section{Conclusion: unreserved politics of reserved labor}

Everyday politics, Ben Kerkvliet avers, 'involves people embracing, complying with, adjusting, and contesting norms and rules regarding authority over, production of, or allocation of resources and doing so in quiet, mundane, and subtle expressions and acts that are rarely organized or direct' (Kerkvliet 2009, 232). The encroachments I refer to in this paper are borne out of NREGA workers ignoring the norms of rural society and undermining the assumptions of those wielding social authority. They do not directly challenge local landowners to combat or engage in class warfare, but use the spaces created by official legislation to lead more dignified lives. Kerkvliet identifies four types of everyday politics, as

the Indian state, with which millions of households in rural India seek to engage. What I want to emphasize by referring to the program as an 'encroachment' is the manner in which it has enabled the rural poor to claim the public space in their villages without having to conform to exploitative social relations and hierarchical intersubjective frameworks. I am also mindful of the descriptive baggage that the term 'encroachment' carries. Across many parts of the world, encroachments are actually enacted by the propertied and the privileged: a study on rural Bihar bears testimony to this (Ekta Parishad and PRAXIS 2009). These encroachments are at the cost of the poor, who are then left with less of the public resources from which to partake. The encroachments I am referring to are directed towards local elites, while drawing on official politics. 
follows: 'support, compliance, modifications and evasions, and resistance' (Kerkvliet 2009, 233). Although he does recognize that peasants might harbor alternative visions, the analytic types highlighted in his work only seem to emphasize the ways in which they defend, protect and preserve these visions. He tells us little about the ways in which the rural proletariat might seek to transform society and the ways in which they might aim to assert those visions in the public space. The encroachments I describe above are quite distinct from Kerkvliet's analytic types. These encroachments need to be examined and analyzed in their own right.

As parliamentarians debated the NREGA, the economist-activist Jean Drèze (2004) made a persuasive case for it, aimed at India's urban, English-reading, middle-class audiences. The NREGA, he argued, would lift masses of the rural poor out of poverty, and keep them from heading for the cities. A third message was that a program such as this would reconfigure social relations in the countryside. While there is considerable debate on whether either of the first two predictions hold, the discussion in this paper does point to the significant ongoing transformation in rural society, to which the NREGA has contributed. By providing work at higher than the market wage rate, it provides the opportunity for agricultural labor households and marginal farmers to claim work in the village, without having to engage in subordinated relations with agriculturalists. Its presence has provided the occasion and the pretext for the proletarianized constituents of the 'peasantry' in rural India to encroach into public domains on their own terms and to cross social limits, much to the trepidation of local elites.

These dynamic tensions resonate with significant reconfigurations in the alliance that made up India's dominant proprietary classes for the better part of its post-colonial history. Bardhan (1984) notes that the uneasy coalition of dominant proprietary classes in India was constituted by three major social groups: large-scale agriculturalists, incipient indigenous capitalists and the salaried groups. Chatterjee (2008) suggests that the 1990s saw a major shift of power within this alliance, with the salaried groups being absorbed into, if not subservient to, the financial-industrial bourgeoisie, and virtually indistinguishable from them. The agrarian elites were faced with declining agricultural productivity, better opportunities in urban areas, increasing returns to investment in towns and the dissipation of the farmers' movements through the 1990s, contributing to the inexorable erosion of their national and regional influence. This is evident from Jayadev et al.'s (2011) analysis of changes in the median wealth of the rural elite: between 1991-92 and 2002-03, the median wealth of the rural elite increased by 2.85 times, lower than the levels of increase experienced by urban elites (3.44), urban middle classes (3.04) and urban manual workers (3.03). In Section 2, I pointed to the ongoing crisis facing agriculture. Although I am skeptical of claims that the Indian villages are 'vanishing' (cf. Gupta 2005), there is little doubt that agrarian elites are facing increasing onslaughts on their influence. The demands posed by the rural proletariat provide an endogenous example of this challenge.

The concentration of wealth in India is increasing, with the top 5 percent of the rural population owning 36 percent of the assets in 2002-03, up from 35 percent a decade earlier (Government of India 2011b, 105). This makes welfare governmentality, embodied in programs such as the NREGA, imperative for the neoliberal Indian state. The agrarian crisis that provided the backdrop of the program is only likely to intensify in the foreseeable future. On the one hand, more and more agriculturalists can expect to swell the ranks of the rural proletariat. On the other hand the elites with which this ever-growing proletariat will have to contend are not likely to be any less exploitative. They will enjoy the full backing of the state as well as of global capital. This should alert India's rural proletariat, and their supporters and sympathizers, to the struggles ahead. The political selves they forge through 
their 'encroachments' into social privileges and through their assertions of dignity will hold them in good stead in these forthcoming struggles.

\section{References}

Akram-Lodhi, H. and C. Kay. 2009. Neoliberal globalisation, the traits of rural accumulation and rural politics: the agrarian question of the twenty-first century. In: H. Akram-Lodhi and C. Kay, eds. Peasants and globalisation: political economy, rural transformation and the agrarian question. London: Routledge, pp. 314-38.

Amin, S. 1995. Event, metaphor, memory: Chauri Chaura 1922-1992. Delhi: Oxford University Press.

Bardhan, P. 1984. The political economy of development in India. Oxford: Oxford University Press.

Breman, J. 1996. Footloose labour: working in India's informal economy. Cambridge: Cambridge University Press.

Bayat, A. 2000. From 'dangerous dlasses' to 'quiet rebels': politics of the urban subaltern in the global south. International Sociology, 15(3), 533-557.

Bayat, A. 2010. Life as politics: How ordinary people change the Middle East. Stanford: Stanford University Press.

Bayly, S. 1999. Caste, society and politics in India from the eighteenth eentury to the modern age. Cambridge: Cambridge University Press.

Bernstein, H. 2001. The peasantry' in global capitalism: who, where and why? Socialist Register, 37, $25-51$.

Bird, K., A. McKay and I. Shinyekwa. 2002. Isolation and poverty: The relationship between spatially differentiated access to goods and services and property. London: Overseas Development Institute.

Borras Jr., S. 2009. Agrarian change and peasant studies: changes, continuities and challenges- an introduction. Journal of Peasant Studies, 36(1), 5-31.

Briggs, A. 1959. The age of improvement. Harlow: Pearson.

Chatterjee, P. 2008. Democracy and economic transformation in India'. Economic \& Political Weekly, 43(6), 53-62.

Corbridge, S., G. Willams, M. Srivastava, and R. Veron (2005) Seeing the State: Governance and Governmentality in India. Cambridge: Cambridge University Press.

Drèze, J. 2004. Employment as a social responsibility. November 21. The Hindu.

Drèze, J. 2011. The battle for employment guarantee. In: R. Khera, ed. Battle for employment guarantee. Delhi: Oxford University Press, pp. 3-20.

Ekta Parishad and PRAXIS. 2009. Landlessness and social justice: an assessment of disparities in land distribution and prospects of land reforms. Patna: PRAXIS.

Frankel, F. 1989 'Caste, Land and Dominance in Bihar: Breakdown of the Brahmanical Social Order'. In: Frankel and MSA Rao, eds. Dominance and State Power in Modern India: Decline of a Social Order. Oxford: Oxford University Press, pp. 46-132.

Government of India. 2005. The National Rural Employment Guarantee Action 2005 (NREGA): Operational Guidelines, Ministry of Rural Development, Department of Rural Development, Government of India, New Delhi. Accessed in December 2011 from http://nrega.nic.in/Nrega guidelinesEng.pdf

Government of India. 2006. Rural Labor Enquiry. New Delhi: Ministry of Labour.

Government of India. 2008. Report on Conditions of Work and Promotion of Livelihoods in the Unorganised Sector. New Delhi: Academic Foundation.

Government of India. 2010. Wage rates in rural India: 2009-10. New Delhi: Ministry of Labor.

Government of India. 2011a. Population Census. New Delhi: Ministry of Home Affairs.

Government of India. 2011b. Human Development Report 2011. New Delhi: Planning Commission.

Government of India. 2011c. Wage rates in rural India: 2010-11. New Delhi: Ministry of Labor.

Government of India. 2012a. Agricultural Census 2010-11: All India Report on Number and Area of Operational Holdings. New Delhi: Ministry of Agriculture.

Government of India. 2012b. Wage rates in rural India: 2011-12. New Delhi: Ministry of Labor.

Government of India. 2013. Union Budget 2013-14. New Delhi: Ministry of Finance.

Government of India. n.d. a. Crop Production Statistics for West Bengal, accessed from http://lus. dacnet.nic.in/dt_lus.aspx 
Government of India. n.d. b. Crop Production Statistics for Bihar, accessed from http://lus.dacnet.nic. in/dt_lus.aspx

Government of India. n.d. c. Minimum Support Prices, accessed from http://eands.dacnet.nic.in/msp/ MSP_4th-Sep-English.pdf

Government of India. n.d. d. District-wise distribution of characteristics of holdings by size class/ size group, accessed from http://agcensus.dacnet.nic.in/StateSizeClass.aspx

Government of India. n.d. e. R3.1. Work demand pattern during the Financial Year. New Delhi: Ministry of Rural Development. accessed from http://164.100.129.6/netnrega/demand_emp_ demand.aspx?1flag=eng\&file $1=$ dmd\&fin=2012-2013\&fin_year=2012-2013\&source=national \& Digest=7sh/qh1hueZ26CmIIyNRAw.

Government of India. n.d. f. Statewise notified wages for NREGA. New Delhi: Ministry of Rural Development, accessed from http://nrega.nic.in/nerega_statewise.pdf

Government of West Bengal. 2007. Human Development Report Maldah, Accessed from http://www. undp.org/content/dam/india/docs/hdr_malda_2006_full_report.pdf

Guha, S. 1996. Time and Money: The Meaning and Measurement of Labour in Indian Agriculture. In: P. Robb, ed. The meanings of agriculture. Delhi: Oxford University Press, pp. 251-261.

Gupta, D. 2005. Whither the Indian village: culture and agriculture in rural India. Economic and Political Weekly, 40(8), 751-758.

Gutmann, M. 1993. A critique of the theory of everyday forms of resistance. Latin American Perspectives, 20(20), 74-92.

Hart, G. 1991. Engendering everyday resistance: gender, patronage and production politics in rural Malaysia. Journal of Peasant Studies, 19(1), 93-121.

Hauser, W. 1993. Violence, Agrarian Radicalism and Electoral Politics. Journal of Peasant Studies, 21(1), 85-126.

Herring, R. and R. Edwards. 1983. Guaranteeing employment to the rural poor: social functions and class interests in the Employment Guarantee Scheme in western India. World Development, 11 (7), 575-592.

Hobsbawm, E.1959. Primitive rebels: studies in archaic forms of social movement in the 19th and 20th centuries. London: W. W. Norton.

Jayadev, A., S. Motiram and V. Vakulabharnam. 2011. Patterns of wealth disparities in India. In: S. Ruparelia, S. Reddy, J. Harriss and S. Corbridge, eds. The great transformation? Understanding India's new political economy. London and New York: Routledge, pp. 81-100.

Karan, A. 2003. Changing pattern of migration from rural Bihar. In: G. Iyer, ed. Migrant Labor and Human Rights in India. Delhi: Kanishka, pp. 102-140.

Kerkvliet, B. 2009. Everyday politics in peasant studies (and ours). The Journal of Peasant Studies, 36(1), 227-43.

Khera, R. 2011. The battle for employment guarantee. Delhi: Oxford University Press.

Khera, R. and N. Nayak. 2011. Women workers and perceptions of the NREGA. In: R. Khera, ed. Battle for Employment Guarantee. Delhi: Oxford University Press, pp. 81-104.

Kunnath, G. 2012. Rebels from the mud-houses: Dalits and the making of the Maoist revolution in Bihar. New Delhi: Social Sciences Press.

Manor, J. and R. Jenkins (forthcoming) Politics and the Right to Work: India's National Rural Employment Guarantee Act. London/ New York: Hurst/ Oxford University Press.

Mintz, S. 1974. The rural proletariat and the problem of the rural proletariat consciousness. Journal of Peasant Studies, 1(3), 291-325.

Popkin, S. 1977. The rational peasant: the political economy of rural society in Vietnam. Berkeley and Los Angeles: University of California Press.

Reddy, D. and S. Mishra. 2009. Agriculture in the Reforms Regime. In: D. Reddy and S. Mishra, eds. Agrarian Crisis in India. Delhi: Oxford University Press, pp. 3-43.

Rodgers, G. and J. Rodgers. 2001. A leap across time: When semi-feudalism meets the market in rural Purnia, Economic and Political Weekly, 36(22), 1976-1983.

Rodgers, G. and J. Rodgers. 2009. Inclusive development? Migration, governance and social change in rural Bihar, Economic and Political Weekly, 46(23), 43-50.

Roy, I. 2013. Development as dignity: dissensus, equality and contentious politics in Bihar, Oxford Development Studies, 41(4), 517-536.

Sainath, P. 2011a. Census findings point to decades of rural distress. September 25. The Hindu.

Sainath, P. 2011b. Decadal journeys: debt and despair spur urban growth. September 26. The Hindu. 
Scott, J.C. 1985. Weapons of the weak: everyday forms of peasant resistance. New Haven: Yale University Press.

Scott, J.C. 2011. The art of not being governed. New Haven: Yale University Press.

Sharma, A. 1995. Political economy of poverty in Bihar. Economic and Political Weekly 30(41-42), $2587-2602$.

Sharma, A. 2005. Agrarian change and socio-economic change in Bihar, Economic and Political Weekly, 40(10), 960-972.

Tilly, C. 1999. Durable Inequality. Berkeley and Los Angeles: University of California Press.

Vasavi, A 2012. Shadow spaces: suicides and the predicament of rural India. Delhi: Three Essays Collective.

White, C.P. 1986. Everyday resistance, socialist revolution and rural development: the case of Vietnam. Journal of Peasant Studies, 13(2), 49-63.

Williams, G., R. Veron, S. Corbridge and M. Srivastava. 2003. Participationand power: poor people's engagement with India's employment assurance scheme. Development and Change, 34(10), $163-192$.

Witsoe, J. 2013. Democracy against development: lower caste politics and political modernity in postcolonial India. Chicago: University of Chicago Press.

Indrajit Roy is at the University of Oxford where he is completing a manuscript on Restive subjects: the politics of the poor, due to be published by Cambridge University Press. His core intellectual interests focus on the political sociology of economic transition with a special focus on the 'emerging markets' India, Brazil and South Africa. His research is located at the intersection of the the ways in which the poor imagine membership in the political community and, the institutions through which states govern economically, socially and culturally heterogeneous populations. Email: indrajit.roy@qeh.ox.ac.uk 